\title{
A TECHNO-ECONOMIC FEASIBILITY ANALYSIS FOR THE GASIFICATION OF SCRAP TIRES FOR ENERGY GENERATION IN TURKEY
}

\author{
Iskender Gökalp ${ }^{1, *}$, Oguz Kaya ${ }^{2}$, Serden Keçecioglu ${ }^{3}$ and Deger Boden ${ }^{4}$ \\ ${ }^{1}$ Centre National de la Recherche Scientifique - ICARE, 1C Avenue de la Recherche Scientifique 45071 Cedex 2, Orléans, France \\ ${ }^{2}$ PRO-SIS Mühendislik, Pro-Sis Enerji Teknolojileri Mühendislik ve Üretim Ltd. Mustafa Kemal Mahallesi, 2146 Sok. No: 7/8, 06520 \\ Cankaya, Ankara, Turkey \\ ${ }^{3}$ Kristal Partners, Istiklal Caddesi Tünel Meydanı, Geçit Han C Blok, No.130, 34430 Beyoğlu, Istanbul, Turkey \\ ${ }^{4}$ Boden-Law, Maslak Mahallesi, iz Plaza Giz No:9, 34398 Sarıyer, Istanbul, Turkey
}

Article Info:
Received:
19 February 2019
Revised:
25 June 2019
Accepted:
02 July 2019
Available online:
22 August 2019
Keywords:
End-of-life tire
Gasification
Electricity generation
Techno-economic feasibility

\section{INTRODUCTION}

End-of-life tires ("ELT") constitute a global and growing environmental issue. We must deal with their recycling and/ or disposal in an environment-friendly manner. According to reports from the largest associations of tire and rubber manufacturers, about 1 billion new units of end-of-life tires are turning into waste annually and must be properly managed. In some parts of the World, hundreds of millions of tires are stockpiled and are posing severe health problems:

"They are breeding grounds and havens for mosquitoes and other vectors, resulting in the spread of dengue fever, yellow fever, encephalitis, West Nile virus, and malaria. Once ignited, tire fires are difficult to extinguish. When water is applied to fight the fire, serious air, ground water, and surface water contamination may result. Toxic emissions from tire fires, such as sulfuric acid and gaseous nitric acid, can irritate the skin, eyes, and mucus membranes, and can affect the central nervous system, cause depression, have negative respiratory effects and, in extreme cases, cause mutations and cancer" (EPA, 2010).

In better regulated geographies, ELTs are used either in recycling (granulation) or in energy generation. However, recycling is just a palliative care which does not address the absolute removal of the waste. On the other hand, the demand for scrap tires from the recycling industry is not sustainable and reliable. As for the energy recovery, the main user of scrap tires is cement kilns. The problem with this type of use is pollutant emissions from scrap tire combustion.

As detailed in the later sections, gasification of scrap tires is a clean technology that only generates a synthetic gas with a high calorific value. When granulated scrap tires are gasified with the appropriate technology, about 95\% in mass are transformed into synthetic gas and the remaining is just inert ash (inorganics). Therefore, gasification of ELT offers the solution for an absolute disposal of scrap tires while proposing an economically beneficial and sustainable energy production route. This work is a techno-economical study of ELT gasification for energy generation based on our previous studies on solid fuel gasification and on a thorough analysis of regulatory and financial conditions prevalent in Turkey.

\section{REGULATORY ASPECTS OF THE ELT SEC- TOR IN TURKEY}

Waste-to-Energy programs are among the most impor-
Detritus / Volume 07 - 2019 / pages 68-75

https://doi.org/10.31025/2611-4135/2019.13843

(C) 2019 Cisa Publisher. Open access article under CC BY-NC-ND license 
tant priorities of International Financial and Developmental Institutions (IFDIs), such as World Bank, IFC and EBRD. According to "IFC Climate Implementation Plan, April 2016", sustainable waste management projects are estimated to triple in the fastest growing low to middle income countries driven by a growing waste problem, enhanced regulatory environment, increased public pressure, urbanization and land scarcity. IFC's waste management strategy has four pillars: Focus on waste-to-energy, refuse-derived fuel, e-waste recycling and integrated waste management (IFC, 2016).

In addition to the IFDIs, local banks, green bond issuers and green funds are seeking investment opportunities that have solid financials and addressing global environmental issues. Consequently, it is very likely to easily have access to local and international long term project financing with competitive pricing for ELT gasification projects.

In Turkey, over the last decade, policymakers have taken important measures to diversify the energy supply mix of the country and to reduce reliance on imported natural gas for power generation. To this aim, the Government has been supporting the use of non-fossil energy sources (hydro-electricity, wind, solar, geothermal, biomass, etc.) throughout long term governmental offtake agreements.

"The Law on the Utilisation of Renewable Energy Resources for the Purpose of Generating Electrical Energy", published in May 2005, initiated attractive feed-in tariff mechanisms to encourage renewable energy investors. In June 2016, an amendment to the above-mentioned law enlarged the definition of "biomass" and included "by-products formed after the processing of scrap tires" into its definition. As a consequence, generating electricity using the synthetic gas produced by scrap tire gasification has become eligible to benefit from 13.3\$ Cent/kWh feed-in tariffs for the first 10 years of operations. It is also possible to receive additional incentives for the first 5 years of operations if locally manufactured equipment is used. Under such conditions, the 10-year Government offtake supported by the feed-in tariffs makes the ELT Gasification not only an environmental sustainability project but also a highly profitable investment decision.

\subsection{Supply of scrap tires}

Scrap tires constitute a global environmental issue but also they are a valuable resource. To address the environmental issue and to benefit from its economic value, developed economies, mainly EU, US and Japan, have adopted local regulatory measures over the past decades.

"The cornerstone of an effective scrap tire management program is developing diverse applications, or purposes for which to apply this resource, preferably ones that (i) can be developed reasonably quickly; (ii) use large quantities; iii) are technically and environmentally sound; and (iv) are economically feasible and sustainable. The largest application in the United States, Europe, and Japan, among others, is using scrap tires as a supplemental energy resource" (EPA, 2010).

EU appears to have the best practice in the World, given the success of its ELT recovery program. Turkey has also chosen to deploy European Union's environmental practices and has adopted "Extended Producer Responsibility (EPR)" approach in 2006, to implement an effective scrap tire management program. Extended producer responsibility means that the original manufacturer has a duty of care to ensure that the waste from the products it has created is disposed of responsibly, in an environmentally sound manner. This makes the producer responsible for the waste that the consumer generates.

This Extended Producer Responsibility may be implemented in various ways: (i) by a single ELT management company dealing with ELT collection and treatment in the country, such as in Portugal, the Netherlands or Sweden; (ii) by multiple ELT management companies, such as in Italy, France or Spain; or (iii) by individual producers' responsibility such as in Hungary. EPR is today the most widespread system in Europe with 21 countries (most of EU28 countries + Norway and Turkey) having adopted a legal framework assigning the responsibility to the producers (tire manufacturers and importers) to organise the management chain of ELTs (ETRMA, 2015).

In Turkey, a Communiqué regarding end-of-life tires has been drafted by the Ministry of Environment and Urbanisation and published in the Official Journal on $25^{\text {th }}$ of November 2006. The Communiqué identifies the roles and responsibilities of all relevant parties to create an effective ELT management program. According to the article 17 of the Communiqué, all manufacturers (including the authorised importers) are obliged to collect end-of-life tires from the local market and they should submit proving documents regarding the disposal and/or recycling of collected tonnage to the Ministry. The required amount of collection is equal to $80 \%$ of the previous year's domestic sales to the replacement market by the relevant vendor. Given the loss of the caoutchouc during the life of the tire, $80 \%$ collection rate is assumed to correspond to the full recovery of the tires sold in the domestic market.

In April 2007, major tire manufacturers and importers in Turkey, namely BRISA, CONTINENTAL, GOODYEAR, MICHELIN and PIRELLI came together to establish LASDER, the Association of Tyire Manufacturers. With the subsequent participation of BAYTUR, INCITAŞ and ANLAŞ, the Association is now serving as the only organisation to implement the Extended Producer Responsibility Program on behalf of 8 the member firms.

\subsection{Volume of the End-of-Life Tires in Turkey and its present use}

World tire market has grown $12 \%$ since 2011 to reach 1.77 Billion units of sale in 2016. The same year, In Turkey, 22.6 Million units have been sold to domestic market. 16 million tires (70\%) were sold to the "replacement" market and the remaining 6.6 million were sold to car manufacturers. According to ELT management approach, the total amount of tires sold on a specific market is equal to an equal amount of used tires dismounted from vehicles (1:1 correlation). This is generally the case, except for winter tires. Therefore, in Turkey, tire manufacturers and importers 
are obliged to collect $80 \%$ of the tonnage equivalent of 16 million tires sold to the domestic replacement market. This amount roughly corresponds to $80 \%$ of 300,000 tons per year, which is 240,000 tons per year. As a comparison, one can estimate that the World tire market has to deal with $\sim 19$ million tons of scrap tires annually. EU used tire stock is estimated to $\sim 4$ million tons per year.

LASDER member companies are controlling about $70 \%$ of the replacement market in Turkey. Therefore, LASDER's mission is to coordinate and control the collection and disposal/recovery of $\sim 168,000$ tons of scrap tires annually, through a tender process. Apart from LASDER, management of remaining ELTs are under the responsibility of other producers and importers which control 30\% market share in the replacement market. However, according to 2015 results shared by the Ministry of Environment, 137,000 tons of ELTs have been effectively managed, which corresponds to a $\sim 57 \%$ success rate $(137 \mathrm{~K} / 240 \mathrm{~K})$. LASDER has successfully managed 110,000 tons of ELT and other players have managed to dispose/recycle only 27,000 tons of scrap tires.

The potential of the ELT market in Turkey is summarised in Table 1. This table also contains information on the amount of granulated tires, given a widely accepted yield rate of $65 \%$, after removing all the metallic and textile parts and also taking into account lost caoutchouc during the granulations processes.

\subsubsection{Recycling (Granulation) - (Tire-Derived Materials TDM)}

In Europe, the ELT sector is evenly divided between recycling and energy recovery. However, in Turkey, material recycling has a larger portion, given the unstable demand of cement kilns (depending on the price of alternative fuels). Tires are made from a range of constituent components such as rubbers, steel, and textiles. The types of rubbers vary with the type of tire and the compounds used. The ratio of steel may vary from one tire type to another, and textiles are generally only used in passenger car and light truck tires today. In the case of granulation, when nonrubber parts are separated from the rubber, there remains about $65 \%$ of the scrap tire.

The rubber in recycled tires is often treated as a complex resource and recycled in its entirety as shred, crumb, granulate or powder. Each of these stages of size reduction has its own characteristics and properties and a given size reduction is used for a specific end-product (ETRMA, 2015). Granulated rubber is used in "rubberised asphalt", "athletic tracks", "stadium surfaces" and in "rail transpor-

TABLE 1: The present potential of the ELT market in Turkey.

\begin{tabular}{l|c}
\hline Total sales to replacement market (tons) & 300,000 \\
\hline Legal obligation of ELT management & $80 \%$ \\
\hline Annual tonnage of ELT to be managed (tons) & 240,000 \\
\hline Percentage of granulated tyre out of ELT & $\sim 65 \%$ \\
\hline Maximum possible amount of granulated ELT (tons) & 156,000 \\
\hline Market share of LASDER member firms & $\sim 70 \%$ \\
\hline LASDER's maximum possible granule output (tons) & 109,200 \\
\hline
\end{tabular}

tation" for noise mitigation and anti-vibration solutions. In Turkey, there is a much more limited use and mainly in "child parks", "synthetic football pitches", and "animal beds". In many cities, small to medium scale firms have invested into scrap tire granulation technology. It should however be noted here that the use of used tire granules for synthetic sport lawns is a controversial issue for its potential health hazards (Environmet \& Human Health Inc., 2017).

\subsubsection{Energy Recovery - (Tire-Derived Fuel TDF)}

The single highest volume and quickest route to the valorisation of scrap tires is to use them for their heat energy content and cement kilns are the main users for tire derived fuel (TDF). In the EU, $\sim 49 \%$ of ETLs go to the energy recovery market and $91 \%$ of them are used in cement kilns (ERTMA, 2015). In Turkey, each year 3 to 6 cement producers join the LASDER tender for their upcoming fuel needs. Out of 300,000 tons of total inquiries, a maximum of 60 70,000 tons are received from cement factories. Capacity utilisation of cement plants, on the one hand, alternative fuel (natural gas, sewage sludge) costs, on the other hand, determine the effective demand of cement producers in the ELT market. However, there are environmental concerns regarding scrap tire combustion even under controlled conditions such as in cement kilns. Under such conditions combustion emissions are much lower compared to uncontrolled combustion (such as stockpiled tire fires). But serious concerns still exist on the full controllability of tire combustion in cement kilns (EPA, 1997; Richards and Agranovski, 2017).

Pyrolysis is another TDF use technology. Pyrolysis is the thermal decomposition under oxidant free environment where the decomposition products are combustible gases, liquid components (pyrolytic oil) and carbon black. This technology has also been tried in Turkey but it is now clear that this process is not sustainable both economically and environmentally. The liquid components are mostly heavy hydrocarbons that need refining to be used as fuel to be converted into energy in a clean way and the market for carbon black is mostly missing.

\section{THE PROPOSED TECHNOLOGY: GASIFI- CATION OF ELT GRANULES}

Carbon containing materials are used for energy production since ages: wood, coal, oil and natural gas are the main such materials transformed into heat and power by combustion. This thermochemical process converts the organic source into $\mathrm{CO}_{2}$ and $\mathrm{H}_{2} \mathrm{O}$ but also to other emissions such as nitric and sulphur oxides and particulates matter (soot), and of course ash in the case of coal or biomass.

Carbon containing energetic materials can be classified in two types: Fossils (such as coal, oil and natural gas, mainly) on the one hand, and biomass and other organic materials such as various waste streams both municipal and industrial, on the other hand. This last category is named "renewable" as biomass can be grown in short and continuous periods and waste streams are also generated on a continuous basis by human activity.

The fuels under the fossils category have been accu- 
mulated in the Earth underground during a process of several hundred million years (due to the decomposition and compression of various biomass resources). Therefore, they are of a given (finite) amount by definition and subject to depletion. Coal and natural gas power plants emit huge amounts of $\mathrm{CO}_{2}$ hence contribute to the global warming issue. Combustion of "new" biomass (not fossilized) can be considered as $\mathrm{CO}_{2}$ free because of the reuse of the emitted $\mathrm{CO}_{2}$ for plant growth through photosynthesis.

\subsection{General considerations on solid fuel gasification}

Gasification of scrap tires is a clean technology that only generates synthetic gas (essentially $\mathrm{CO}, \mathrm{H}_{2}, \mathrm{CH}_{4}$ and $\mathrm{CO}_{2}$ ) with a high calorific value. De-metallized and granulated (with dimensions of few millimetres) scrap tires can be efficiently gasified in well-designed fluidized bed gasifiers. As a result about $95 \%$ in mass of the granulés are transformed into synthetic gas and the remaining is just inert ash (inorganics). After some cleaning, the energetic gas can be converted into electricity in gas engines (with an efficiency of about $40 \%$ ). The available engine waste heat can also be recovered and used as process heat or steam or for heating purposes and even to generate additional electricity using a Rankine cycle turbine.

Gasification studies of carbon containing materials have a long history. The first large scale application goes back to coal gasification in Germany to produce synthetic gas from which synthetic liquid fuels were generated during the Second World War. This process was further developed during the post-war period in South Africa by the company Sasol.

Gasification can be best explained as incomplete combustion. By reducing the amount of the air (and thus of the oxygen) supplied to oxidize, for example, coal, the oxidation process is limited and instead of $\mathrm{CO}_{2}+\mathrm{H}_{2} \mathrm{O}$ as end-products in complete combustion, one obtains a gaseous mixture composed essentially of $\mathrm{H}_{2}+\mathrm{CO}$, called synthetic gas or syngas. This produced gas is obviously reactive and can be burned in a gas turbine, a gas engine or in a burner similar to natural gas. Compared to the direct combustion of coal (or biomass etc.) the gasification temperatures in the gasification reactor are lower; this reduces the production of pollutant emissions such as nitric and sulphur oxides. Furthermore, without going into details, we can also mention that gasification permits more easily the capture $\mathrm{CO}_{2}$ (pre-combustion capture) compared to direct combustion (post-combustion capture).

The produced gas (syngas) can be combusted to generate heat and power but can also be further processed essentially by catalytic processes (as in the German example we mentioned above). In addition, gasification is also a hydrogen production process. Gasification systems can handle several feedstocks and also co-gasification approaches are possible such as co-gasification of coal and biomass blends. Gasification is therefore a multi fuel and multi product technology.

The quality of the syngas (its calorific value, the $\mathrm{H}_{2}$ / $\mathrm{CO}$ ratio etc.) depends on many parameters such as the gasification temperature, the oxygen/fuel ratio, the residence time of the fuel within the gasifier, but also on the gasification reactor design. To optimize the gasification process for a given feedstock, several studies should be conducted, starting with laboratory type studies to determine the gasification kinetics (essentially the carbon conversion rate meaning that in the ideal case there should be no carbon atom in the ashes) using sophisticated laboratory equipment and several thermochemical computation techniques. Once this gasification thermochemistry is established, pilot and demonstration facilities can be designed, built and operated. All these studies contribute to give confidence to move to commercial level designs at various capacity levels, to build up the learning by doing process and initiate a virtuous cycle for unit cost reduction. There are several reviews in the literature which justify the advantages of scrap tire gasification (Molina et al., 2013; Oboiriena and Northa, 2017; Machin et al., 2017; Rowhani and Rainey, 2017). The present work is based on our previous studies concerning solid fuel gasification research and fluidized bed gasification demonstration facilities.

\subsection{Previous studies on which this project is based}

Several previous studies conducted by our team paved the way for the proposed technology. First, the gasification kinetics has been established in laboratory type studies for various scrap tire samples (both for cars and trucks). These studies used thermogravimetric analyzers coupled with mass spectrometry and gas chromatography to characterize used tire gasification kinetics (for various heating rates up to $1000 \mathrm{~K} / \mathrm{min}$, gasification temperatures between 800 and $900^{\circ} \mathrm{C}$ and for different gasification agents such as air, steam and $\mathrm{CO}_{2}$ and their various mixtures (Kandasamy and Gökalp, 2015).

The pilot and demonstration phases have also been accomplished for the gasification of lignite in the framework of a large-scale European Union FP7 project (the OPTIMASH project, 2011-2016, supported by the EU for about 5.5 million Euros). Within the OPTIMASH project a $1 \mathrm{MWth}$ high pressure circulating fluidized bed gasifier was designed, built, commissioned and successfully tested. This facility is now in operation at the company THERMAX in Pune, India (Figure 1). The Turkish Coal Enterprise TKI was also a partner of this project, together with the French CNRS, IIT Madras, India and ECN, Netherlands (Kandasamy and Gökalp, 2018). The present project is therefore capitalizing on this accumulated knowledge and expertise.

\subsection{Technical and financial characteristics of the project}

We designed a scrap tire gasification facility of $5 \mathrm{MWe}$ capacity using gas engines, shown schematically in Figure 2. The gasification reactor design is adapted to the thermo-physical characteristics of various scrap tire samples especially the gasification kinetics, obtained during laboratory studies. Based on the expertise gained during the OPTIMASH project, a circulating fluidized bed gasifier for various thermal capacities has been designed. The synthetic gas obtained from the gasification island is cleaned 


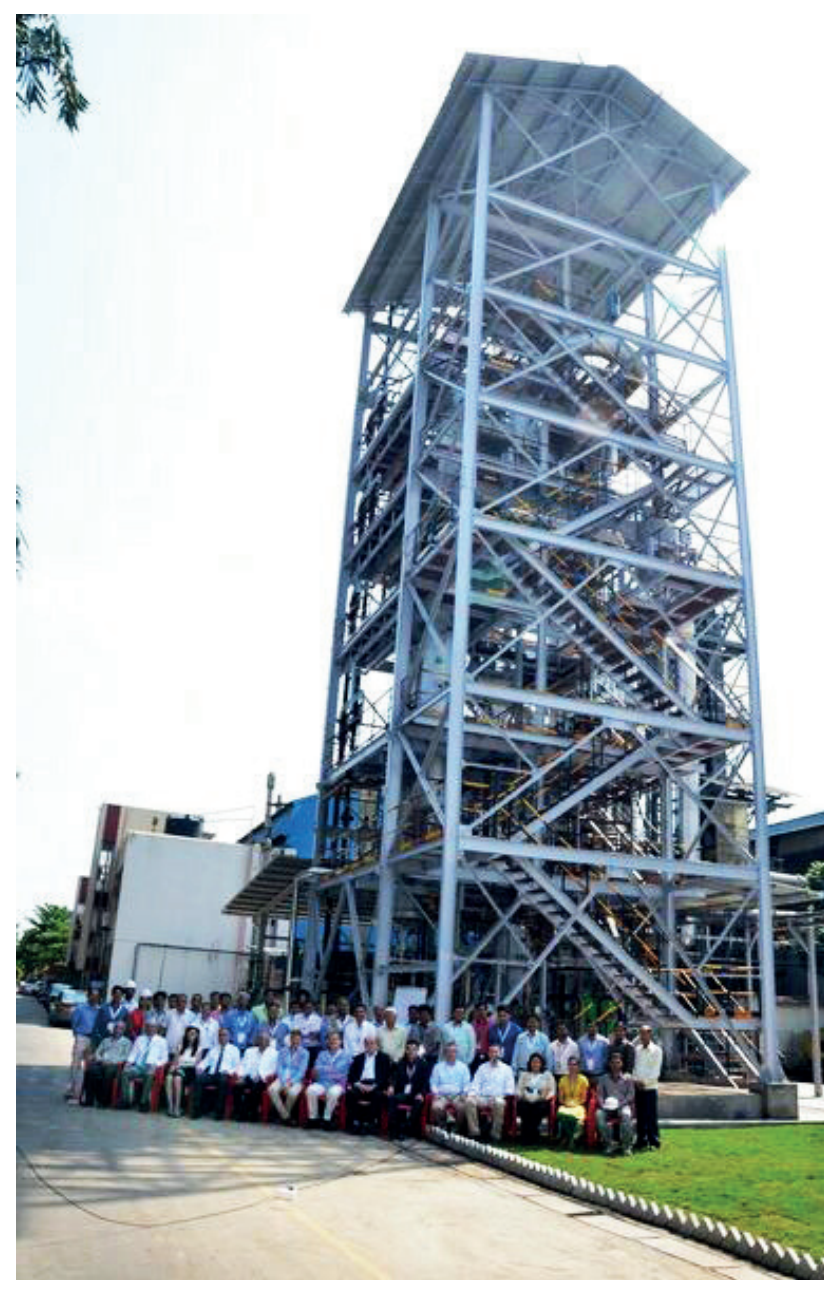

FIGURE 1: $1 \mathrm{MW}$ th circulating fluidized bed solid fuel gasification facility developed during the FP7 OPTIMASH project (2011-2016).

and converted to heat and power in gas engines. The most critical and innovative part of this system is obviously the gasification reactor. Its design criteria are based on our knowledge, experience and expertise in the gasification area. The circulating fluidized bed gasifier uses a mixture of preheated air and steam as the gasification agent. A global layout of the gasification facility is presented on Figure 2.

The power plant consists basically of the following elements:

- the scrap tire granules storage area and feeding system, together with the limestone and silica sand storage and feeding areas;

- the gasification reactor composed mainly of the circulating Fluidized Bed Reactor with its support structure, cyclone separator, loop-seal system, start-up burner, primary \& secondary air fans, ash take-off system with ash cooler screw, cooling water system with circulating water cooling radiators, air preheater, primary \& secondary air pipes, instruments, valves and dampers, MCC \& control panel;

- the reactor steam supply system mainly composed of the superheated steam boiler where the required heat shall be provided by the hot syngas through a heat recovery system, feed water pumps, deaerator and storage tank with instruments, valves, water treatment unit with storage tank, MCC \& control panel;

- the syngas system with the syngas piping ensemble including the by-pass system, the syngas heat recovery system and/or syngas cooler with air, instruments and control dampers;

- the syngas cleaning system with spray scrubber 1 and 2 , condenser with gas/water separator, bag filter protected with nitrogen, circulating water system with waste water treatment, circulating pumps;

- the flare system with the knock-out drum, the water seal tank, flare LPG pilot flame, control panel;

- the gas engine generator sets including lube oil system, intake air filters, generator control panel, fuel control skid, start air system, acoustic enclosure, exhaust gas system and stack, air ducts and radiators also including the gas engines heat recovery system with the engines' jacket water heat exchangers, exhaust gas boiler with valves \& pumps.

The flare system will insure the safe disposal of syngas during start-up or short term upsets. The flare includes a LPG fired pilot flame to ensure that the flare is continually operating. Water for gas cleaning and cooling will be used in a circulating way without any environmental pollution after it is treated through water treatment facilities. A small amount of make-up water will be however required. The main water loss is through the steam to be fed to the gasification reactor to increase the gasification efficiency.

We expect to reach 8,000 hours of net operations annually. This will allow a net electricity generation of about $40,000,000 \mathrm{kWh}$. The yearly needed scrap tire granules amounts to about 14,000 tons. The technical and financial details of the facility are given in the sections below.

\subsubsection{Gasification mass and energy balance details}

The gasification reactor is based on the circulating fluidized bed concept that we optimized in the OPTIMASH project (Kandasamy and Gökalp, 2018). The main advantages of this technology are its high conversion efficiency, its fuel flexibility, high turn-down ratio and low emissions. The heat and mass balances of the gasification reactor are based on the determination of the scrap tire samples gasification kinetics in detailed laboratory studies (Kandasamy and Gökalp, 2015). The average scrap tire characteristics that we used for the heat and mass balances are presented in Table 2.

The gasification reactor mass balance only for electricity is given in Table 3 for a reactor bed temperature of $850^{\circ} \mathrm{C}$ and for a cold gas efficiency of $70 \%$.

To generate electricity from syngas, we use $3 \mathrm{GE}$ Jenbacher J620 GS-F63 gas engines with 40\% efficiency. Under such conditions the net electricity efficiency of the system is $26.3 \%$. Using the data given by GE, we estimated the waste heat recovery potential from the engine cooling water and the hot exhaust gases. From the 3 engines, the recoverable cooling water heat (as hot water) 


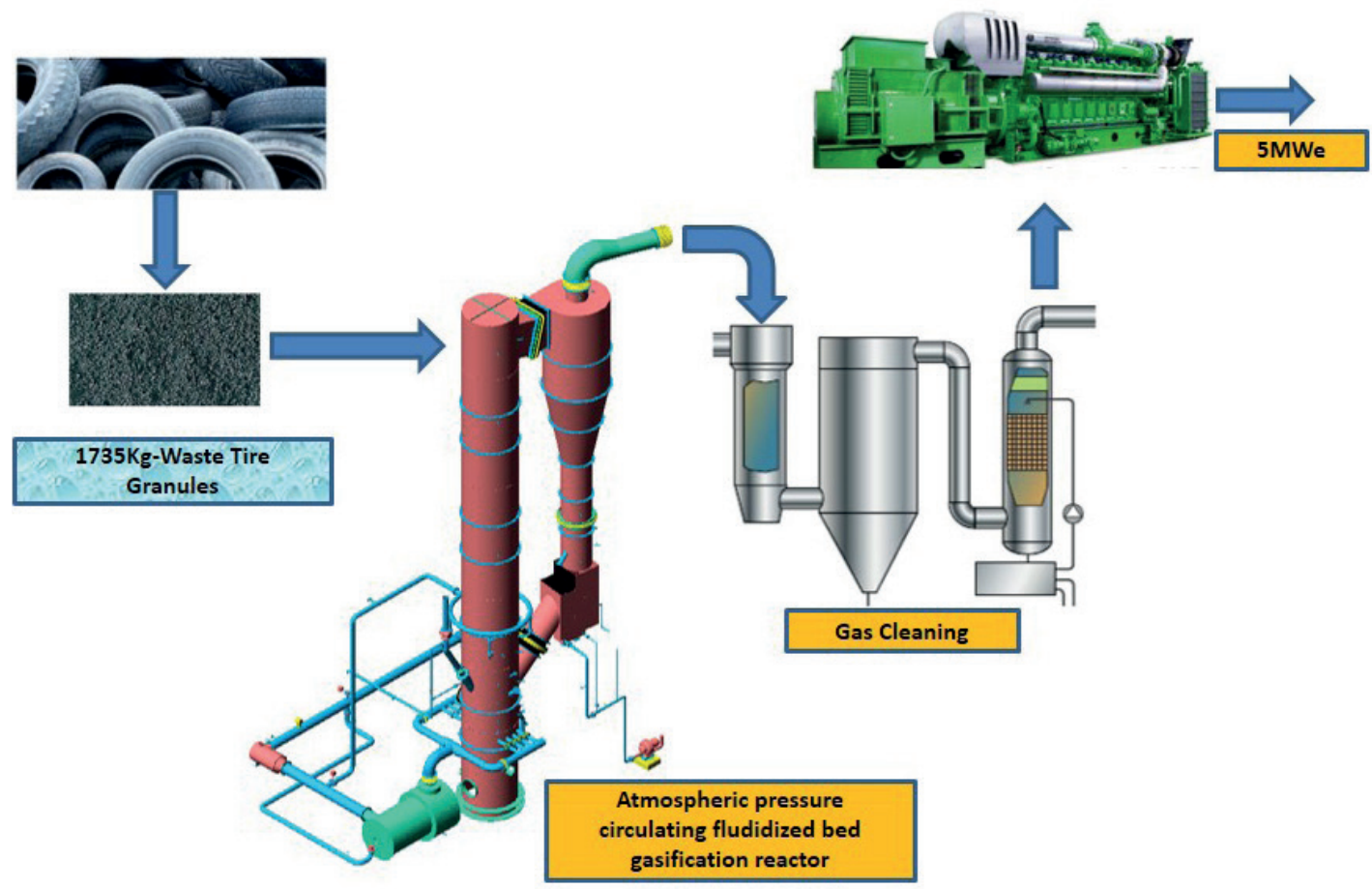

FIGURE 2: Schematic presentation of the 5 MWe scrap tire gasification and electricity generation facility designed based on the technology developed during the OPTIMASH project.

is $2607 \mathrm{kWth}$ and the recoverable heat (as steam) from the exhaust gases is $3465 \mathrm{kWth}$, giving a total recoverable heat of $6072 \mathrm{kWth}$. For the exhaust gases case, the hot gas temperature is given as $465^{\circ} \mathrm{C}$ by GE. We cooled down the gases to $155^{\circ} \mathrm{C}$ to be ejected from the chimney and

TABLE 2: Averaged characteristics of scrap tire samples used for the energy and mass balances of the gasification reactor.

\begin{tabular}{|c|c|}
\hline Total humidity \% & 1.09 \\
\hline Ash \% & 4.95 \\
\hline Volatile matter $\%$ & 73.74 \\
\hline Fixed carbon \% & 20.22 \\
\hline $\mathrm{C} \%$ & 81.46 \\
\hline $\mathrm{H} \%$ & 6.84 \\
\hline $\mathrm{N} \%$ & 2.27 \\
\hline $\mathrm{S} \%$ & 1.38 \\
\hline 0 & 2.01 \\
\hline LHV / HHV, kcal/kg & 8478 / 8853 \\
\hline
\end{tabular}

TABLE 3: Mass balance for 5000 kWe generation.

\begin{tabular}{l|c}
\hline Scrap tire granules flow rate & $1735 \mathrm{~kg} / \mathrm{h}$ \\
\hdashline Air flow rate & $6250 \mathrm{~kg} / \mathrm{h}$ \\
\hline Steam flow rate & $780 \mathrm{~kg} / \mathrm{h}$ \\
\hline Ash flow rate & $86 \mathrm{~kg} / \mathrm{h}$ \\
\hline Syngas flow rate & $8529 \mathrm{Nm}^{3} / \mathrm{h}$ \\
\hline Syngas LHV & $5276 \mathrm{~kJ} / \mathrm{Nm}^{3}$ \\
\hline Syngas HHV & $5713 \mathrm{~kJ} / \mathrm{Nm}^{3}$ \\
\hline Electric generation / Net & $5000 \mathrm{kWe} / 4500 \mathrm{kWe}$ \\
\hline
\end{tabular}

we accepted a heat loss coefficient of $2 \%$. Under those conditions, the total energy efficiency of the system becomes $61.7 \%$. To estimate the natural gas equivalent of the recovered heat, we used a natural gas with a calorific value of $8250 \mathrm{kcal} / \mathrm{Nm}^{3}$ and a boiler efficiency of $94 \%$. Under such conditions the natural gas equivalent of the total recoverable heat is $673 \mathrm{Nm}^{3} / \mathrm{h}$. These figures will be used below for the financial analysis of the project.

\subsubsection{Financial details of the project}

A full economic feasibility analysis has been performed using various sensitivity parameters and options, for a 30 years operation period of the facility. One important parameter is the cost of waste tire granulés. A detailed sensitivity analysis has been performed for this parameter, including the options of either buying the granulés from the market (with long term purchase agreements) or investing in a waste tire granulés production facility. Initial investment costs (capex + opex during the facility installation and commissioning phases) and the opex for the facility running phase have been estimated. Different loan strategies have been also investigated (including a preferential loan possibility through the EBRD). The operating phase opex also considers the maintenance of the whole system including the gas engines. Finally the generated cash flow, the NPV and the IRR have been calculated for two scenarios. One scenario considers only the electricity generation sold using the power purchase agreement mentioned above. The second scenario also includes the valorization of the waste heat from the engines and valued at the market price of natural gas to generate the same heat output. In both cases the IRR is much higher than other renewable energy investments. The details of 
the cost-income analysis are given in Table 4 where more conservative efficiency figures than above are used. The cost for a ton of scrap tire granules is taken here as 80 USD / ton. To estimate the yearly income figures, the government feed in tariff of $0.15 \mathrm{USD} / \mathrm{kWe}$ and the substituted natural gas price of $222 \mathrm{USD} / \mathrm{Nm}^{3}$ are used.

\section{CONCLUSIONS}

A techno-economic feasibility analysis for a $5 \mathrm{MWe}$ scrap tire granulés gasification facility is presented. Electricity generation is based on gas engines with the option of waste heat recovery. Based on our previous work, it is demonstrated that the best thermochemical option for waste tire disposal and energetic valorization is gasification using a mixture of preheated air and steam as the gasification agent. Also based on our previous work, the best gasification technology is shown to be the circulating fluidized bed technology. The study shows that under the regulatory and financial conditions prevalent in Turkey, the project is both technically and economically feasible.

The existing and upcoming ELT volumes in Turkey tells us that an installation of $10 \mathrm{MWe}$ capacity power plant, fed by about 30,000 tons of granulated scrap tire per year, has no supply risk. The installed capacity shall be gradually increased to $30 \mathrm{MWe}$, provided that tire manufacturers and their related body, LASDER, support the use of scrap tire in energy recovery. In order to achieve 30 MWe installed capacity, about $60 \%$ of the annual scrap tire tonnage $(90,000$ tons in granulé form) have to be allocated to ELT gasification.

Given the fact that 20 million tons of ELTs should be managed worldwide each year, power generation capacities of hundreds MW can be installed all around the World based on the Turkish examples The eagerness of IFDIs, private lenders and regulators creates a favourable investment climate to boost this development. Such an expansion requires obviously due diligence to understand the supply side and sell side risks of the relevant country jurisdictions.

\section{ACKNOWLEDGMENTS}

This work has benefited from the support of the Conseil Regional Centre, France through the project VALESTO to establish the chemical kinetics of the scrap tire gasification. It has also benefited from the support of the European Commission to Project OPTIMASH, FP7-ENERGY, 2011-2016, Project No 283050 for the optimization of the circulating fluidized bed gasification system.

\section{REFERENCES}

Air Emissions from Scrap Tire Combustion, 1997. U.S. Environmental Protection Agency

Environment \& Human Health, Inc., 2017. Synthetic turf. Industry claims versus the Science, $112 \mathrm{p}$.

EPA, 2010. Scrap Tires: Handbook on Recycling Applications and Management for the U.S. and Mexico. U.S. Environmental Protection Agency

ETRMA, 2015. End-of-life Tyre Report 2015. European Tyre \& Rubber Manufacturers' Association
TABLE 4: A financial feasibility analysis for 5MW electricity generation from scrap tire gasification under Turkish economic conditions.

\begin{tabular}{|c|c|}
\hline \multicolumn{2}{|c|}{ AIMED POWER OF THE PLANT: 5 Mwe (5000 kWe) } \\
\hline \multicolumn{2}{|c|}{ NECESSARY SCRAP TIRE FLOW RATE : $1735 \mathrm{~kg} / \mathrm{h}$} \\
\hline \multicolumn{2}{|c|}{ AUTO CONSUMPTION OF THE PLANT : 500 kWe } \\
\hline \multicolumn{2}{|c|}{ NET ELECTRICTY GENERATION POWER : 4500 kWe } \\
\hline \multicolumn{2}{|c|}{ GLOBAL PLANT EFFICIENCY FOR ELECTRIC GENERATION ONLY : \% 25} \\
\hline \multicolumn{2}{|c|}{$\begin{array}{l}\text { GLOBAL PLANT EFFIICIENCY FOR ELECTRIC GENERATION + WASTE } \\
\text { HEAT USE : } \% 59\end{array}$} \\
\hline INVESTMENT COST OF THE PLANT & USD \\
\hline BUILDINGS CONSTRUCTION & 320,000 \\
\hline GRANULATED TIRE FEEDING SYSTEM & 190,000 \\
\hline GASIFICATION ISLAND & $1,750,000$ \\
\hline GAS CLEANING ISLAND & 850,000 \\
\hline 3 GAS ENGINES & $2,625,000$ \\
\hline FLARE AND OTHER TUBING & 190,000 \\
\hline ELECTRIC SYSTEM & 280,000 \\
\hline CONTROL AND AUTOMATION SCADA & 350,000 \\
\hline ENGINEERING & 150,000 \\
\hline TOTAL & $6,705,000$ \\
\hline
\end{tabular}

\section{YEARLY OPERATING COST}

\begin{tabular}{l|c}
\hline COST OF TIRES PREPARED FOR GASIFICATION & $2,435,000$ \\
\hdashline OPERATIONAL COST OF THE PLANT & 580,000 \\
\hdashline MAINTENANCE & 250,000 \\
\hdashline INSURANCE & 25,000 \\
\hdashline TOTAL & $\mathbf{3 , 2 9 0 , 0 0 0}$ \\
\hline
\end{tabular}

\begin{tabular}{l|c}
\hline YEARLY INCOME (0.15 USD/kWe and 8000 hour/year) & $5,400,000$ \\
\hline NET YEARLY INCOME & $2,110,000$ \\
\hline RETURN ON INVESTMENT (electricty generation only) & 3,2 YEAR \\
\hline
\end{tabular}

WHEN THE WASTE HEAT IS USED

\begin{tabular}{|c|c|}
\hline TOTAL AVAILABLE HEAT & $6,018 \mathrm{kWth}$ \\
\hline NATURAL GAS EQUIVALENT & $696 \mathrm{Nm}^{3} / \mathrm{h}$ \\
\hline ADDITIONAL INCOME (222 USD / $\mathrm{Nm}^{3} / \mathrm{h}$ ) FOR 8000 HOURS & $1,776,000$ \\
\hline TOTAL INCOME & $7,176,000$ \\
\hline TOTAL NET INCOME & $3,886,000$ \\
\hline ADDITIONAL INVESTEMENT TO USE THE WASTE HEAT & 600,000 \\
\hline TOTAL INVESTMENT COST & $7,305,000$ \\
\hline RETURN ON INVESTMENT (electricity + waste heat) & 1,9 YEAR \\
\hline
\end{tabular}


IFC, 2016. Climate Implementation Plan

Kandasamy Jayarama and Gökalp Iskender, 2015. Pyrolysis, Combustion, and Steam Gasification of Various Types of Scrap Tires for Energy Recovery. Energy \& Fuels 29, 346-359

Kandasamy Jayaraman and Gökalp Iskender, 2018. Pyrolysis and Gasification Characteristics of High Ash Indian and Turkish Coals in http://dx.doi.org/10.5772/intechopen.73536 Chapter 11, pp. 209235

Machin Einara Blanco, Travieso Pedroso Daniel, de Carvalho Júnior João Andrade, 2017. Technical assessment of discarded tires gasification as alternative technology for electricity generation. Waste Management 68, 412-420
Molino Antonio, Alessandro Erto, Francesco Di Natale, Antonio Donatelli, Pierpaolo lovane and Dino Musmarra, 2013. Gasification of Granulated Scrap Tires for the Production of Syngas

and a Low-Cost Adsorbent for Cd(II) Removal from Wastewaters. Ind. Eng. Chem. Res. 52, 12154-12160

Oboiriena, B.O and Northa, B.C., 2017. A review of waste tyre gasification. Journal of Environmental Chemical Engineering 5, 51695178

Richards Glen and Agranovski Igor E., 2017. Dioxin-like pcb emissions from cement kilns during the use of alternative fuels. Journal of Hazardous Materials 323, 698-709

Rowhani Amir and Thomas J. Rainey, 2016. Scrap Tyre Management Pathways and Their Use as a Fuel-A Review. Energies 9, 888 